\title{
PENGARUH CARA PENGOLAHAN DAN WAKTU BERBEDA TERHADAP KADAR PROTEIN DAGING BEKICOT (ACHANTINA FULICA) SEBAGAI SUMBER PROTEIN ALTERNATIF MASYARAKAT NEGERI LESLURU KECAMATAN TEON NILA SERUA (TNS) WAIPIA
}

\author{
Rofli J. Lessu', Mery Pattipeilohy ${ }^{2}$, Stevin Melay ${ }^{2}$ \\ ${ }^{1}$ Alumni Program Studi Pendidikan Biologi \\ ${ }^{2}$ Program Studi Pendidikan Biologi \\ E-mail: pattipeilohymery@yahoo.com
}

\begin{abstract}
Background: Snail (Achantina fulica) is one of the animals from the gastropod class. Snails are often consumed by the Lesluru people as an alternative source of protein for fish substitutes. This study aims to determine the levels of snail meat protein which is processed by boiling, fumigation and frying, as well as providing information on the nutritional content of snails for the community in general.

Method: The type of research used is experimental research and to test the protein content using the kjeldhal method. This research was conducted from November 4 to November 12, 2018.

Results: This study was analyzed using the normality test, homogeneity test and followed by ANOVA test. In analyzing the data used the SPSS Windows version 16.0 program help. The results of the analysis of protein content of snail meat, known, the highest levels found in the treatment by fumigation with an average protein content of $40.4 \%$ while the lowest protein content found in boiling processing with an average protein content of $27.0 \%$.
\end{abstract}

Conclusion: treatment by fumigation while the lowest protein content is found in the treatment by boiling.

Keywords: Snail meat (Achantina fulica), protein content, kjeldhal method.

\begin{abstract}
Abstrak
Latar Belakang: Bekicot (Achantina fulica) adalah salah satu hewan dari kelas gastropoda. Bekicot sering dikonsumsi oleh masyarakat Negeri Lesluru sebagai sumber protein altrnatif pengganti ikan. Penelitian ini bertujuan untuk mengetahui kadar protein daging bekicot yang diolah dengan cara perebusan, pengasapan dan digoreng, sekaligus menjadi bahan informasi mengenai kandungan gizi pada bekicot bagi masyarakat secara umum.

Metode: Tipe penelitian yang digunakan adalah penelitian eksperimental dan untuk menguji kandungan protein menggunakan metode kjeldhal. Penelitian ini dilaksanakan mulai dari tanggal 4 November - 12 November 2018.

Hasil: Penelitian ini dianalisis menggunakan uji normalitas, uji homogenitas dan dilanjutkan dengan uji ANOVA. Dalam menganalisis data digunakan bantuan program SPSS Windows versi 16,0. Hasil analisis kadar protein daging bekicot, diketahui, kadar yang paling tinggi terdapat pada pengolahan dengan cara pengasapan dengan rata-rata kadar protein sebesar $40,4 \%$ sedangkan kadar protein terendah terdapat pada pengolahan dengan cara perebusan dengan rata-rata kadar protein $27,0 \%$.

Kesimpulan: perlakuan dengan cara pengasapan sedangkan kadar protein terendah terdapat pada perlakuan dengan cara perebusan.
\end{abstract}

Kata kunci: Daging bekicot (Achantina fulica), kadar protein, metode kjeldhal. 


\section{PENDAHULUAN}

Bekicot (Achantina fulica) adalah salah satu hewan dari kelas gastropoda (Campbell, dkk, 2000). Bekicot memiliki protein hewani yang sangat tinggi. Kandungan protein pada bekicot sebesar $59,28 \%$, lemak $3,62 \%$, serat kasar $2,47 \%$, kalsium $6,4 \%$ dan fosfor $0,85 \%$ (Kompiang, 1979). Spesies ini dapat hidup di daerah pertanian, wilayah pesisir, lahan basah, hutan alami, semak belukar, dan daerah perkotaan serta bekicot dapat hidup secara liar di hutan maupun di perkebunan atau tempat budidaya (Raut dan Barker, 2002).

Di daerah Kabupaten Maluku Tengah Kecamatan Teon Nila Serua (TNS) Negeri Lesluru terdapat masyarakat yang sering mengkonsumsi bekicot sebagai salah satu sumber bahan pangan dengan cara pengolahan yang berbeda. Daging bekicot dikonsumsi sebagai makanan alternatif pengganti ikan sehubung dengan harga ikan yang mahal, namun secara umum, di Negeri Lesluru daging bekicot biasa diolah dan dikonsumsi dengan cara perebusan, pengasapan dan digoreng, namun tidak semua daging bekicot dimakan oleh masyarakat karena terdapat beberapa jenis bekicot yang beracun, daging bekicot juga sering dikonsumsi pada berapa daerah di Maluku seperti di Maluku Tenggara, Seram, Buru, Saparua, Ambon dan masi banyak daerah lainya yang juga mengkonsumsi daging bekicot ini.

Penggunaan daging bekicot dipilih sebagai salah satu sumber protein alternatif karena kebiasaan masyarakat Negeri Lesluru yang sering mengkonsumsi daging bekicot ini dengan perlakuan berbeda karena dipandang memiliki kandungan gizi yang cukup. Hasil dari penelitian ini dapat diimplikasikan bagi masyarakat Negeri Lesluru dan bagi masyarakat pada umumnya, dalam rangka pemanfaatan daging bekicot sebagai salah satu sumber protein alternatif pengganti ikan sehubung dengan harga ikan yang mahal. Penelitian ini juga akan memberikan informasi bagi masyarakat mengenai kandungan gizi dari daging bekicot yang biasa di komsumsi dengan cara pengolahan yang berbeda sebagai sumber protein alternatif sehingga masyarakt dapat memperoleh pengetahuan serta mengetahui manfaat dari penelitian ini. Agar masyarakat mengetahui manfaat dari daging bekicot maka penulis membuat informasi dalam bentuk leaflet.

Leaflet merupakan media berbentuk selembar kertas yang diberi gambar dan tulisan pada kedua sisi kertas berisi informasi mengenai suatuhal atau peristiwa, dilipat sehingga berukuran kecil dan praktis dibawa. Leaflet ini digunakan untuk mengiklankan atau menyebarluaskan sebuah produk yang belum diketahui sebelumnya sehingga masyarakat Negeri Lesluru Kecamatan Teon Nila Serua (TNS) Waipia dan masyarakat pada umumnya dapat mengetahui kandungan protein dari daging bekicot yang sering dikonsumsi. Leaflet ini akan menjelaskan tentang manfaat, pengolahan serta kandungan protein pada daging bakicot yang diolah dengan cara perebusan pengasapan dan digoreng.

\section{MATERI DAN METODE}

Tipe penelitian yang digunakan adalah penelitian Eksperimental. Jenis penelitian ekperimental adalah suatu pengujian yang dilakukan di Laboratorium. Dengan melihat perbandingan kadar protein daging bekicot berdasarkan cara pengolahan yang berbeda. Pengambilan sampel di Negeri Lesluru, Kecamatan Ton Nila Serua (TNS) Waipia. Analisis protein dilakukan di Laboratorium Kimia Dasar Fakultas Matematika dan IImu Pengetahuan Alam (FMIPA) Universitas Pattimura Ambon. Penelitian ini dilaksanakan mulai dari tanggal 4 November sampai dengan 12 November 2018. Subjek dalam penelitian ini adalah daging bekicot yang diambil dari Negeri Lesluru Sebanyak 20 Sampel. Objek dalam penelitian ini adalah kadar protein daging bekicot berdasarkan pengolahan dan penggunaan waktu yang berbeda. Sampel pada setiap perlakuan adalah seberat 1-2 gram. Variabel bebas dalam penelitian ini adalah daging bekicot yang diolah dengan cara perebusan, pengasapan, dan digoreng. Variabel terikat adalah Kadar protein daging bekicot.

\section{Rancangan Penelitian}

Rancangan dalam penelitian ini adalah rancangan faktoral, menggunakan desain percobaan Rancangan Acak Lengkap (RAL). Penelitian ini determinasi pada 
perbedaan kadar protein daging bekicot yang diolah dengan cara perebusan, pengasapan, dan digoreng dengan 3 perlakuan dan 3 kali ulangan serta satu kali kontrol. Rancangan penelitian dapat dilihat pada tabel 1 berikut ini.

Tabel 1. Rancangan Penelitian

\begin{tabular}{lcc}
\hline $\begin{array}{c}\text { Kode } \\
\text { Sampel }\end{array}$ & Perlakuan & $\begin{array}{c}\text { Waktu } \\
\text { Pengolahan }\end{array}$ \\
\hline K. (Kontrol) & K.0 & - \\
P1. & P1.1 & 10 Menit \\
& P1.2 & 20 menit \\
P2. & P1.3 & 30 menit \\
& P2.1 & 2 menit \\
P3. & P2.2 & 4 menit \\
& P3.1 & 6 menit \\
& P3.2 & 4 menit \\
& P3.3 & 6 menit \\
\hline
\end{tabular}

Keterangan: K. (Kontrol) : 0

PI.1 : Rebus. (10 Menit). P2.1 : Pengasapan. (2 Menit). P3.1 : Goreng. (2 Menit)

PI.2 : Rebus.(20 Menit). P2.2 : Pengasapan. (4 Menit). P3.2 : Goreng. (4 Menit)

PI.3 : Rebus. (30 Menit). P2.3 : Pengasapan. (6 Menit). P3.3 : Goreng. (6 Menit)

\section{Prosedur Penelitian}

\section{Tahap Persiapan}

a. Sampel daging bekicot diambil pada habitat atau tempat yang bersuhu ringan dan tingkat kelembaban yang tinggi.

b. Bekicot yang digunakan sebagai sampel penelitin rata-rata berukuruan $5-7 \mathrm{~cm}$.

c. Bekicot di bersihkan dangan air bersih.

d. Pisahkan daging bekicot dari cangkangnya.

e. Setelah dipisahkan dari cangkangnya daging bekicot dicucui dengan menggunakan air garam secukupnya untuk menghilangkan lendirnya.

f. Daging bekicot yang akan digunakan dibersihkan lagi dengan air, agar bersih dan bebas dari kontaminan.

g. Setelah bersih, daging bekicot di diamkan selama 40 menit.

h. Mempersiapkan alat dan bahan yang di dunakan dalam penelitian.

i. Semua alat yang akan digunakan dibersihkan/disterilkan.

\section{Proses Pengolahan}

a. Pada tahap ini daging bekicot direbus dengan menggunakan panci/wadah memasak dengan perlakuan petama selama 10 menit perlakuan kedua 20 menit dan perlakuan ketiga waktu selama 30 menit dengan suhu $60^{\circ} \mathrm{C}$.

b. Sampel daging bekicot yang diambil dipanggang menggunakan alat pemanggang dengan perlakuan petama selama 2 menit perlakuan kedua 4 menit dan perlakuan ketiga waktu selama 6 menit dengan suhu $60^{\circ} \mathrm{C}$.

c. Sampel daging bekicot yang diambil digoreng dengan menggunakan wajan dengan perlakuan petama selama 2 menit perlakuan kedua 4 menit dan perlakuan ketiga waktu selama 6 menit dengan suhu $60^{\circ} \mathrm{C}$.

\section{Tahap Analisis Protein}

Menurut Geronimo (2011), bahwa uji protein dapat dibagi dalam 9 tahapan, yaitu:

a. Timbang daging bekicot seberat 1-2 gram masukkan dalam labu destruksi, tambahkan 5 gram campuran natrium sulfat dan mercury oxida ( $20: 1$ ) S

b. Tambahkan kedalam labu destruksi 10 $\mathrm{ml}$ asam sulfat pekat

c. Lakukan pemanasan labu destruksi mula-mula 200-250ㄷ sampai larutan tidak berasap lagi, kemudian dilakukan pemanasan pada suhu $300-400^{\circ} \mathrm{C}$ sampai larutan didalam labu destruksi menjadi jernih.

d. Bias labu destruksi dengan aquades dan lakukan pemanasan pada suhu yang sama sampai larutan menjadi jernih.

e. Pindahkan labu destrkusi kedalam alat destilasi dan lakukan pengenceran dengan aquades secukupnya, kedalam labu destruksi tambahkan larutan $\mathrm{NaOH}$ $45 \%$ sampai larutan bersifat alkalis (basa) diuji dengan kertas lakmus.

f. Tempatkan erlenmeyer pada ujung pendingin alat destilasi dengan posisi ujung kondensor harus tercelup dalam larutan penampung (asam boric 5\%).

g. Dilakukan destilasi sampai volume larutan dalam labu destilasi $2 / 3$ telah menguap atau larutan yang keluar dari ujung pendingin alat destilasi tidak bersifat basa lagi (diuji dengan kertas lakmus). 
h. Selanjutnya dilakukan titrasi terhadap larutan yang diperoleh dengan $0,1 \mathrm{NHCl}$ sampai mencapai titik ekuivalen (warna keabu-abuan).

i. Catat jumlah $\mathrm{ml} \mathrm{HCL} 0,1 \mathrm{~N}$ yang digunaan.

\section{Perhitungan Kadar Protein}

a. Kadar Nitrogen Dihitung dengan menggunakan rumus:

$$
\% N=\frac{\text { mlHClsampelXNHClX } 14}{\text { grsampelX } 1000}
$$

\section{Keterangan:}

$\mathrm{ml} \mathrm{HCl}$ : banyaknya $\mathrm{ml} \mathrm{HCl}$ yang digunakan untuk titrasi

$\mathrm{N} \mathrm{HCl}$ : normalitas $\mathrm{HCl}(0,1)$

14: berat atom nitrogen

Setelah dihitung \% N selanjutnya menghitung kadar protein dengan menggunakan factor konversi. Besar factor konversi $\mathrm{N}$ tergantung pada \% $\mathrm{N}$ yang menyusun protein suatu bahan.

b. Menghitung Kadar Protein (\%) $\%$ protein $=\% \mathrm{~N} \times$ factor konversi $(6,25)$

c. Menghitung Rata-Rata Kadar Protein (\%). Menggunakan rumus: Parameter ini dihitung dengan menggunakan rumus sebagai berikut:

$X=\frac{\mathrm{U} 1+\mathrm{U} 2+\mathrm{U} 3}{\mathrm{~N}}$
Dimana:

$X=$ Kadar protein rata-rata

$\mathrm{N}=$ Jumlah ulangan

$\mathrm{U}_{1}+\mathrm{U}_{2}+\mathrm{U}_{3}=$ Jumlah kadar protein pada keseluruhan ulangan.

Teknik Analisis Data

Untuk mengetahui kadar protein dipakai Analisis Varians, dengan menggunakan program SPSS yaitu Anova. Sebelum melakukan uji anova, terlebih dahulu dilakukan uji normalitas menggunakan Kolmogrov-Sminorv Test dan uji homogenitas menggunakan Levene Test. Apabila uji anova menunjukan hasil yang signifikan ( $\mathrm{H} 0$ ditolak) maka dilanjutkan dengan uji post-hock menggunakan Bonferroni dengan tingkat kebermaknaan 0,05 .

\section{HASIL DAN PEMBAHASAN}

Hasil

Analisis Kadar Protein Berdasarkan Metode Kjeldhal

Hasil analisis kadar protein pada sampel daging bekicot berdasarkan cara pengolahan yang berbeda dengan menggunakan metode Kjeldahl dapat dilihat pada tabel berikut. Rata-rata hasil analisis kadar protein pada sampel daging bekicot mentah (kontrol) dapat dilihat pada tabel 2. dan hasil analisis kadar proteinnya dapat dilihat pada gambar 1 di bawah ini.

Tabel 2. Rata-Rata Hasil Analisis Kadar Protein Daging Bekicot Mentah (Kontrol)

\begin{tabular}{cccccc}
\hline No & Ulangan & $\begin{array}{c}\text { Berat } \\
\text { Sampel }\end{array}$ & $\begin{array}{c}\text { MI HCL 0,1 } \\
\mathbf{N}\end{array}$ & $\begin{array}{c}\text { Kadar } \\
\text { Protein }\end{array}$ & $\begin{array}{c}\text { Rata-rata } \\
\text { Kadar Protein }\end{array}$ \\
\hline 1 & U1 & 1,1673 & 19,8 & 14,8419 & 14,8419 \\
\cline { 1 - 1 } & Total \% & & 14,8419 & \\
\hline
\end{tabular}




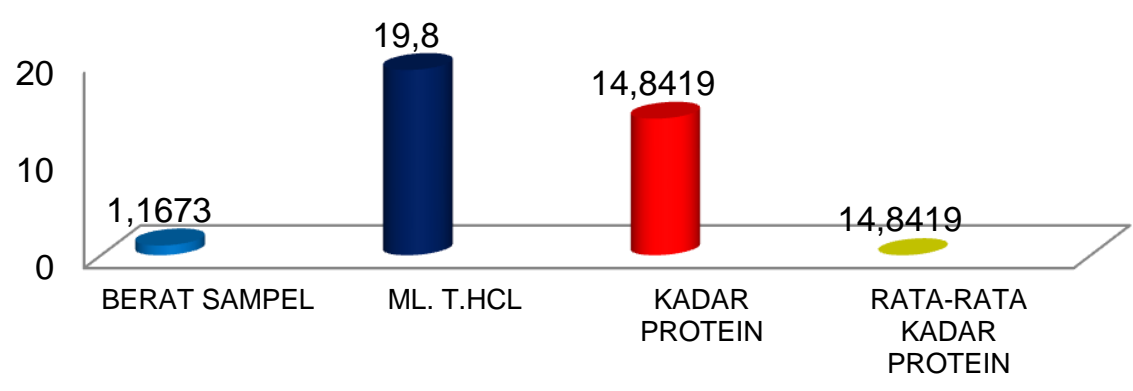

\section{Gambar 1. Grafik Hasil Analisis Kadar Protein Daging Bekicot Mentah (Kontrol)}

Pada tabel 4 terlihat bahwa jenis sampel mentah (kontrol) dengan berat sampel 1,1673 gram dengan volume titrasi HCL sebanyak 19,8 ml, maka kadar protein daging bekicot mentah (kontrol) adalah 14,8419. Dengan nilai rata-rata protein tetap 14,8419. Rata-rata hasil analisis kadar protein daging bekicot yang diolah dengan cara perebusan dapat dilihat pada tabel 3 dan hasil analisis kadar proteinnya dapat dilihat pada gambar 2 di bawah ini.

Tabel 3. Rata-Rata Hasil Analisis Kadar Protein Pada Sampel Daging Bekicot yang Direbus.

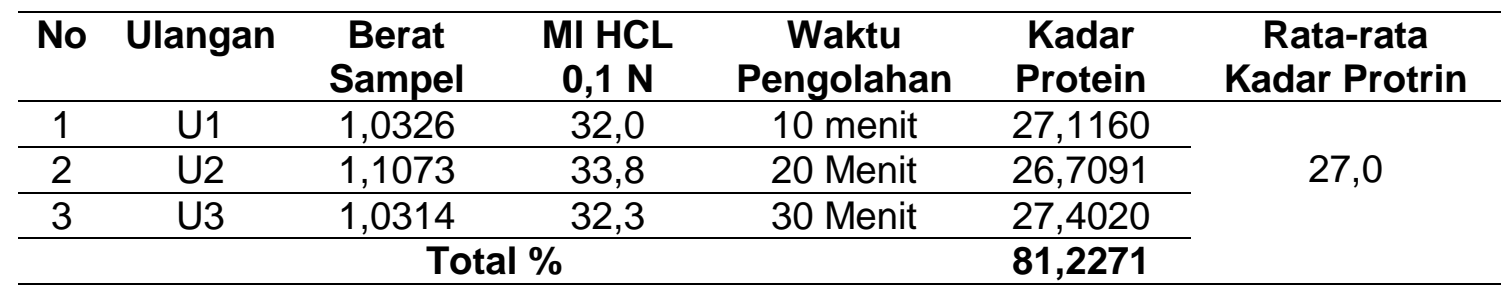

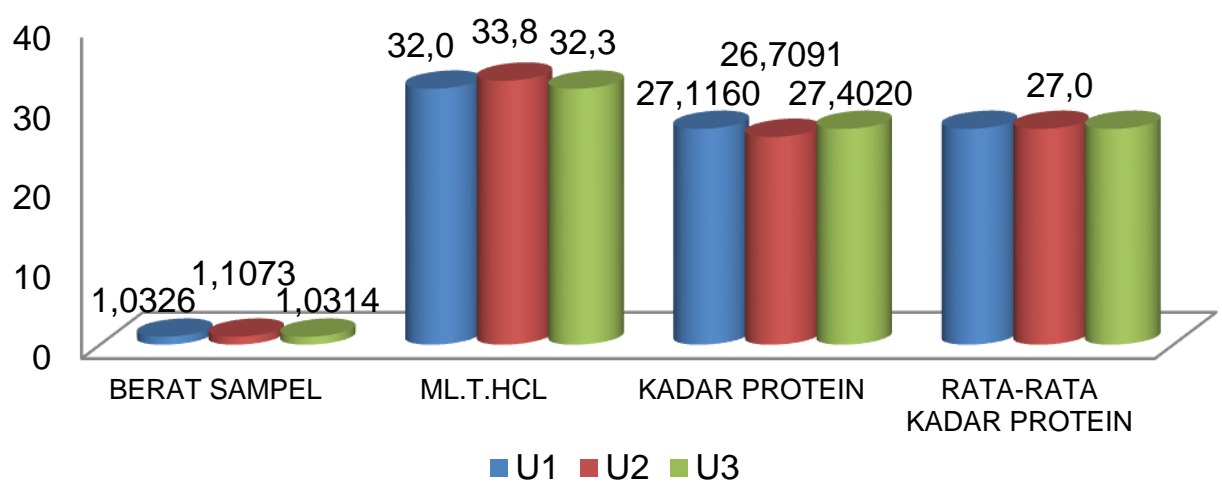

\section{Gambar 2. Grafik Hasil Analisis Kadar Protein Pada Sampel Daging Bekicot yang Diolah Dengan Cara Perebusan.}

Pada tabel 5 terlihat bahwa jenis sampel untuk perlakuan dengan cara perebusan pada U1 dengan berat sampel 1,0326 gram, volume titrasi HCL sebanyak $32,0 \mathrm{ml}$, dengan waktu pengolahan selama 10 menit maka kadar protein daging bekicot adalah 27,2260; pada U2 dengan berat sampel 1,1073 gram, volume $\mathrm{HCL}$ sebanyak 33,8 $\mathrm{ml}$, dengan waktu pengolahan selama 20 menit maka kadar protein daging bekicot adalah 26, 7091; danpada U3 dengan berat sampel 1,0314 gram, volume $\mathrm{HCL}$ sebanyak $32,3 \mathrm{ml}$, dengan waktu pengolahan selama 30 menit maka kadar protein daging bekicot adalah 27,4020 . Dengan jumlah kadar protein pada 
U1, U2, dan U3 total sebesar 81,2271\%, dengan nilai rata-rata adalah 27,0 .

Rata-rata hasil analisis kadar protein daging bekicot yang diolah dengan cara pengasapan dapat dilihat pada tabel 4 dan hasil analisis kadar proteinnya dapat dilihat pada gambar 3. Di bawah ini.

Tabel 4. Rata-Rata Hasil Analisis Kadar Protein Pada Sampel Daging Bekicot yang Diolah Dengan Cara Pengasapan.

\begin{tabular}{|c|c|c|c|c|c|c|}
\hline No & Ulangan & $\begin{array}{c}\text { Berat } \\
\text { Sampel }\end{array}$ & $\begin{array}{c}\text { MI HCL } \\
0,1 \mathrm{~N}\end{array}$ & $\begin{array}{c}\text { Waktu } \\
\text { Pengolahan }\end{array}$ & $\begin{array}{l}\text { Kadar } \\
\text { Protein }\end{array}$ & $\begin{array}{c}\text { Rata-rata } \\
\text { Kadar Protein }\end{array}$ \\
\hline 1 & U1 & 1,0423 & 48,3 & 2 Menit & 40,5473 & \multirow{4}{*}{40,4} \\
\hline 2 & U2 & 1,0345 & 47,7 & 4 Menit & 40,3533 & \\
\hline 3 & U3 & 1,0164 & 47,0 & 6 Menit & 40,4616 & \\
\hline & & Tot & & & 121,3622 & \\
\hline
\end{tabular}

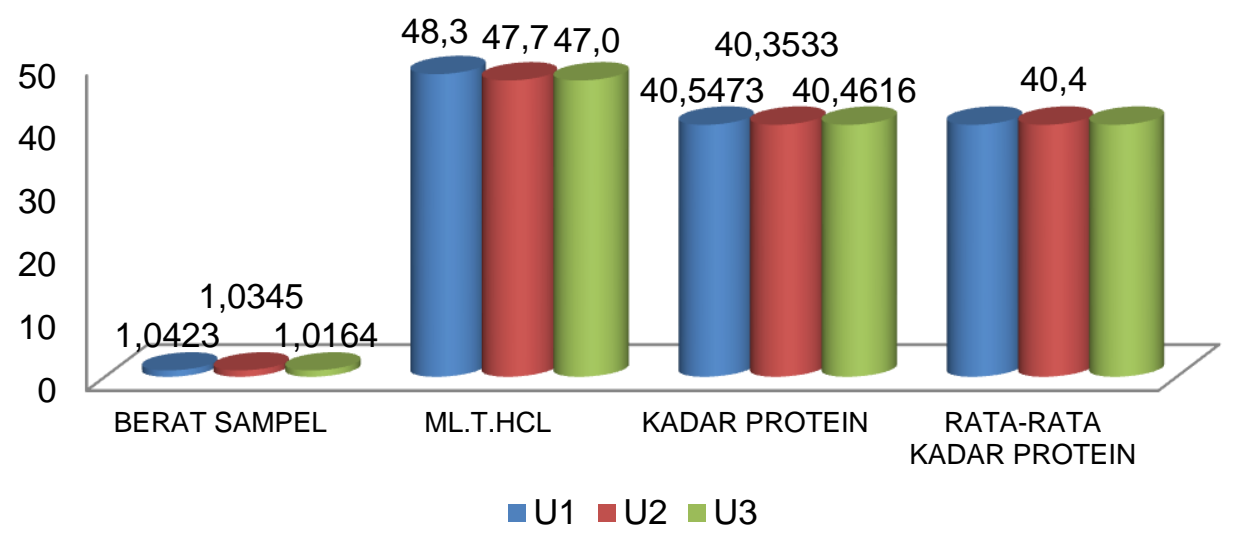

\section{Gambar 3. Grafik Hasil Analisis Kadar Protein Pada Sampel Daging Bekicot yang Diolah Dengan Cara Pengasapan.}

Pada Tabel 6 terlihat bahwa jenis sampel untuk perlakuan dengan cara pengasapan pada U1dengan berat sampel 1,0423 gram, volume titrasi HCL sebanyak $48,3 \mathrm{ml}$, dengan waktu pengolahan selama 2 menit maka kadar protein daging bekicot adalah 40,5473; pada U2 dengan berat sampel 1,0345 gram, volume $\mathrm{HCL}$ sebanyak 47,7 $\mathrm{ml}$, dengan waktu pengolahan selama 4 menit maka kadar protrin daging bekicot adalah 40,3533; dan pada U3 dengan berat sampel 1,0164 gram, volume HCL sebanyak $47,0 \mathrm{ml}$, dengan waktu pengolahan selama 6 maka kadar protein daging bekicot adalah 40,4616 . Dengan jumlah kadar protein pada U1, U2, dan U3 total sebesar $121,3622 \%$, dengan nilai rata-rata adalah 40,4.

Rata-rata hasil analisis kadar protein daging bekicot yang diolah dengan cara digoreng dapat dilihat pada Tabel 5 dan hasil analisis kadar proteinnya dapat dilihat pada gambar 4 di bawah ini.

Tabel 5. Rata-Rata Hasil Analisis Kadar Protein Pada Sampel Daging Bekicot yang Diolah Dengan Cara Digoreng.

\begin{tabular}{|c|c|c|c|c|c|c|}
\hline No & Ulangan & $\begin{array}{c}\text { Berat } \\
\text { Sampel }\end{array}$ & $\begin{array}{c}\text { MI HCL } \\
0,1 \mathrm{~N}\end{array}$ & $\begin{array}{c}\text { Waktu } \\
\text { Pengolahan }\end{array}$ & $\begin{array}{l}\text { Kadar } \\
\text { Protein }\end{array}$ & $\begin{array}{c}\text { Rata-rata } \\
\text { Kadar Protein }\end{array}$ \\
\hline 1 & U1 & 1,0217 & 45,3 & 2 Menit & 38,7956 & \\
\hline 2 & $\mathrm{U} 2$ & 1,0326 & 45,9 & 4 Menit & 38,8945 & 38,8 \\
\hline 3 & U3 & 1,0317 & 45,7 & 6 Menit & 38,7588 & \\
\hline
\end{tabular}




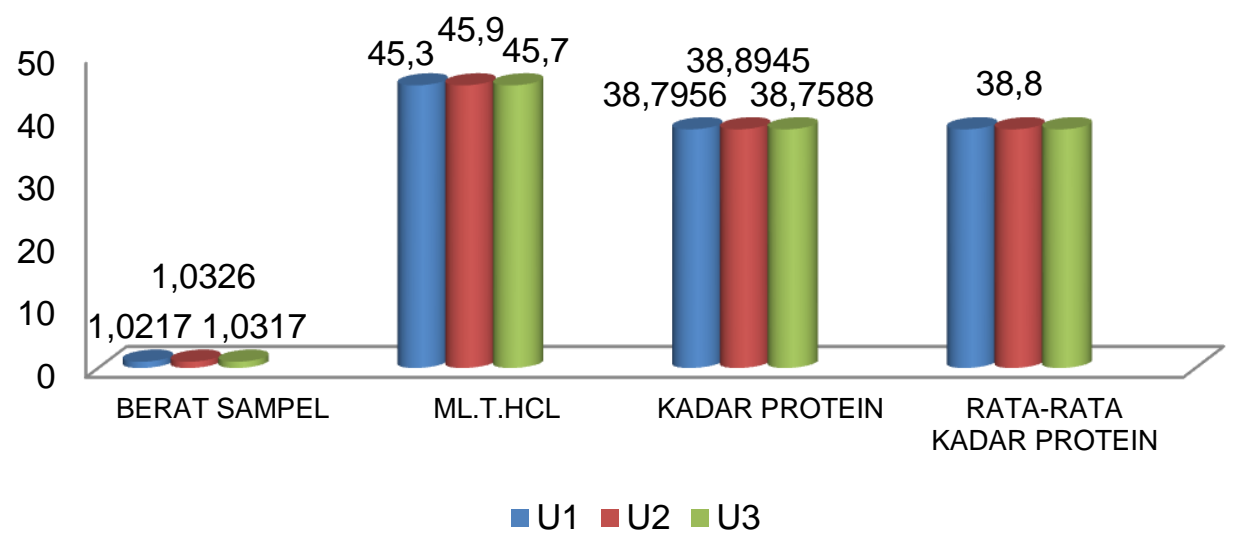

\section{Gambar 4. Grafik Hasil Analisis Kadar Protein PadaSampel Daging Bekicot yang Diolah Dengan Cara Digoreng.}

Pada tabel 5 terlihat bahwa jenis sampel untuk perlakuan dengan cara digoreng pada U1 dengan berat sampel 1,0217 gram, volume titrasi HCL sebanyak $45,3 \mathrm{ml}$, dengan waktu pengolahan selama 2 menit maka kadar protein daging bekicot adalah 38,7956; pada U2 dengan berat sampel 1,0326 gram, volume $\mathrm{HCL}$ sebanyak 44,9 ml, dengan waktu pengolahan selama 4 maka kadar protrin daging bekicot adalah 38,8945 ; dan pada U3 dengan berat sampel 1,0317 gram, volume $\mathrm{HCL}$ sebanyak $45,7 \mathrm{ml}$, dengan waktu pengolahan selama 6 maka kadar protein daging bekicot adalah 38,7588. Dengan jumlah kadar protein pada U1, U2, dan U3 total sebesar $116,4489 \%$, dengan nilai rata-rata adalah 38,8 .

\section{Hasil Analisis Kadar Protein Berdasarkan Uji Anova \\ Data pengukuran kadar protein daging} bekicot kemudian dianalisis menggunakan uji anova satu jalur. Uji anova digunakan untuk mengetahui pengaruh cara pengolahan terhadap kadar protein daging bekicot. Namun sebelum melakukan uji anova dilakukan uji prasyarat normalitas dan homogenitas. Uji normalitas menggunakan uji Shapiro Wilk. Berdasarkan uji Shapiro Wilk diketahui bahwa semua data kadar protein mempunyai signifikan $>\alpha=0.050$, artinya data berditribusi normal. Sedangkan uji homogenitas menggunakan uji Levene. Berdasarkan uji homogenitas diketahui bahwa signifikan $0.131>\alpha=0.050$, artinya data berasal dari populasi yang homogen. Oleh karena data pengukuran kadar protein daging bekicot normal dan homogen, maka uji ANOVA satu jalur dapat dilanjutkan. Uji anova satu jalur ditunjukkan pada tabel 6 . Di bawah ini.

Tabel 6. Hasil Uji ANOVA Pengukuran Kadar Protein Daging Bekicot

\begin{tabular}{lrrrrr}
\hline \multicolumn{1}{c}{ Sumber } & $\begin{array}{c}\text { Jumlah } \\
\text { Kuadrat }\end{array}$ & Df & $\begin{array}{l}\text { Rata-rata } \\
\text { kuadrat }\end{array}$ & F & Sig. \\
\hline Between Groups & 319.472 & 2 & 159.736 & 3524.6 & .000 \\
& & \multicolumn{2}{c}{6} \\
\hline Within Groups & 319.744 & 6 & .045 & & \\
\hline Total & 319.74 & & & \\
\hline
\end{tabular}

Hasil analisis varians pada tabel 6 menunjukkan bahwa variasi cara pengolahan memiliki nilai signifikansi $0,000<\alpha=0,05$, sehingga hipotesis penelitian diterima, artinya terdapat pengaruh cara pengolahan terhadap kadar protein daging bekicot. Selanjutnya dilakukan uji LSD (Least Significance difference) dengan taraf kepercayaan 5\% untuk menentukan perbedaan rata-rata cara 
pengolahan. Hasil uji LSD ditunjukkan pada tabel 7 di bawah ini.

\section{Tabel 7. Hasil Uji LSD Kadar Protein Daging Bekicot}

\begin{tabular}{llc}
\hline Perlakuan & Rata-rata & Notasi \\
\hline Rebus & 27.0757 & $\mathrm{a}$ \\
\hline Goreng & 38.8163 & $\mathrm{~b}$ \\
\hline Asar & 40.4530 & $\mathrm{C}$ \\
\hline
\end{tabular}

Keterangan: a: Notasi a rebus (27.0757)

b: Notasi b goreng (38.8163)

c: Notasi c asar (40.4535)

Berdasarkan tabel 7 diatas diketahui bahwa terdapat perbedaan notasi huruf antara variasi cara pengolahan. Cara pengolahan asar mempunyai kadar protein daging bekicot yang paling tinggi dibandingkan cara pengolahan goreng dan rebus. Oleh karena itu cara pengolahan mempunyainotasi c. Sedangkan kadar protein daging bekicot yang dimasak menggunakan cara pengolahan rebus ditandai dengan notasi a dengan rata-rata kadar protein terendah.

\section{Pembahasan}

Berdasarkan data hasil analisis kadar protein pada daging bekicot yang diolah dengan cara perebusan, pengasapan dan digoreng sebagaimana terlihat pada hasil ditas, membuktikan bahwa pada setiap perlakuan sampel daging bekicot memiliki kadar protein yang berbeda-beda. Dari ketiga perlakuan tersebut kadar protein yang paling tinggi terdapat pada perlakuan pengasapan dengan kode sampel U2 dengan rata-rata kadar protein daging bekicot sebesar 40,4\%, kadar protein yang sedang terdapat pada perlakuan pengorengan dengan kode sampel U3 dengan rata-rata kadar protein sebesar $38,8 \%$ dan kadar protein daging bekicot yang paling rendah terdapat pada perlakuan perebusan dengan kode sampel U1 dengan rata-rata kadar protein sebesar $27,0 \%$. Sedangkan untuk kontrol dengan kode sampel (K) memiliki nilai rata-rata tetap 14,8419 karena tidak menggunakan pengulangan. Menurut Ika (2011), bahwa perbedaan kadar protein yang berbeda disebabkan karena proses pengolahan yang dilakukan, jenis makanan, bentuk tubuh serta adanya perbedaan tingkat kadar air yang berbeda-beda dari setiap bahan pangan. Dalam penelitian ini dilakukan pengulangan untuk menganalisis kadar protein dengan 3 perlakuan dan 3 kali ulangan dengan penggunaan rentang waktu yang berbeda sebagaimana terlihat pada rancangan penelitian diatas, sedangkan untuk kontrol tidak dilakukan pengulangan, hal ini bertujuan untuk mengurangi kesalahan menghitung rata-rata kadar protein pada daging bekicot.

Berdasarkan uji pendahuluan yang dilakukan untuk menentukan perlakukan waktu pada setiap sampel daging bekicot yang diolah dengan cara perebusan, pengasapan dan digoreng maka ditemukan rentang waktu yang signifikan dari ketiga sampel perlakuan tersebut untuk dijadikan sebagai waktu yang paten dalam proses pengolahan pada setiap sampel perlakuan daging bekicot sebagaimana terlihat pada Rancangan penelitian. Tingginya kadar protein pada perlakuan pengasapan dengan kode sampel U2 disebabkan karena kandungan atau kadar air yang berada pada sampel daging bekicot yang diolah dengan cara pengasapan mengalami penguapan seiring dengan lamanya proses pengasapansehingga kadar air pada daging bekicot berkurang atau mengalami penurunan. Lama waktu pengeringan sangat berpengaruh terhadap kadar protein daging bekicot. Peningkatan jumlah kadar protein pada perlakuan pengasapan dengan kode sampel U2 disebabkan oleh rendahnya kadar air sehingga kadar protein meningkat. Buckle., dkk (1987), menyatakan bahwa semakin tinggi kadar protein semakin rendah kadar airnya begitu juga sebaliknya. Hal yang sama juga dikemukakan oleh Adawyah (2007), bahwa kandungan air pada bahan makanan dapat mempengaruhi kandungan gizi dari bahan makanan tersebut.

Selain itu yang mempengaruhi kadar protein karena terjadinya denaturasi (Dewi, 2001). Pemanasan protein dapat menyebabkan rekasi denaturasis. Denaturasi adalah perubahan struktur molekul tanpa memutuskan ikatan peptida. nilai nutrisi protein tidak hilang karena denaturasi, bahkan mungkin bertambah dari zegi gizi, denaturasi protein dapat meningkatkan daya cerna suatu protein (Diniz., dkk 2013). Kadar protein pada 
daging bekicot juga dapat dipengaruhi oleh beberapa faktor, yaitu suhu, pada lingkungan hidup bekicot tersebut, $\mathrm{pH}$ dan faktor lingkungan lainya dalam proses metabolisme (Prayogo, 2011). Suhu, pH, dan faktor lingkungan sangat berkaitan erat dengan proses metabolisme dimana proses metabolisme tersebut terdapat berbagai reaksi kimia yang akan menentukan kadar protein pada bekicot tersebut. Reaksi kimia ini merupakan bagian dari sistem yang bekerja spesifik metebiolisme dan menghasilkan senyawa-senyawa kimia (Pharmacy, 2011).

Girard (1992), menjelaksan bahwa pengasapan bertujuan untuk menurunkan kadar air dan mendapatkan tekstur yang baik, pengunaan panas dalam pengolahan bahan pangan dapat menurunkan presentase kadar air sehingga mengakibatkan meningkatnya presentase kadar protein. Hal serupa juga dikemukakan oleh Riansyah., dkk (2003), bahwa kenaikan nilai kadar protein terus berlangsung dengan semakin lamanya waktu yang digunakan selama proses pengeringan. Sejalan dengan pernyataan Winarno., dkk (1982), bahwa dengan mengurangnya kadar air, bahan pangan akan mengandung senyawa-senyawa seperti protein, karbohidrat, lemak, dan mineral dalam konsentrasi lebih tinggi. Selain itu tingginya kadar protein pada sampel daging bekicot yang diolah dengan pengasapan ditentukan oleh jumlah $\mathrm{mL}$ $\mathrm{HCL}$ yang digunakan menitrasi basil destilasi yang ditampung (rata-rata $47,6 \mathrm{~mL}$ titran $\mathrm{HCL}$ ). Banyaknya volume $\mathrm{HCL}$ yang digunakan sebagai titiran menunjukan bahwa kadar protein pada sampel daging bekicot yang diolah dengan cara pengasapan cukup tinggi. Rendahnya kadar protein pada perlakuan perebusan dengan kode sampel U1 dan U2 disebabkan karena kadar air yang masi banyak sehingga dapat mempengaruhi kadar protein. Penggunan panas pada proses pengolahan bahan pangan seperti perebusan, pengasapan, dan digoreng dapat mempengaruhi nilai gizi bahan pangan (Sundari dan Lamid, 2015). Apabila suhu yang digunakan dalam proses pengolahan mencapai $\pm 160^{\circ} \mathrm{C}$, maka sebagaian zat gizi akan mengalami kerusakan (Khomsan, 2002). Hal yang serupa juga dikemukakan Prabandari, $d k k$
(2005), bahwa waktu dan suhu pengolahan dapat memengaruhi nilai kadar air suatu bahan pangan, semakin lama waktu pengolahan dan semakin tinggi suhu yang digunakan akan mengakibatkan banyak air dalam bahan pangan keluar. Hasil uji anova satu arah terlihat $F_{\text {hitung }}$ adalah 352,466 dengan signifikansi $0,000<\alpha=0,05$, maka rata-rata kadar protein untuk masingmasing perlakuan daging bekicot berbeda secara nyata. Uji lanjut LSD (least Significance difference) menunjukan bahwa kadar protein daging bekicot antara perlakuan 1 , perlakuan 2 dan perlakuan 3 berbeda. Perbedaan yang nyata kadar protein daging bekicot antara perlakuan, terutama terkait dengan rata-rata kadar protein yang dihasilkan. Perlakuan 2 merupakan perlakuan yang menghasilkan kadar protein tertinggi, perlakuan 1 dan 3.

\section{KESIMPULAN}

Terdapat perbedaan rata-rata kadar protein daging bekicot yang diolah dengan cara perebusan, pengasapan dan digoreng. Kadar protein tertinggi terdapat pada perlakuan dengan cara pengasapan sedangkan kadar protein terendah terdapat pada perlakuan dengan cara perebusan.

\section{DAFTAR PUSTAKA}

Adawyah, R. 2007. Pengolahan dan Pengawetan Ikan. Bumi Aksara. Jakarta.

Buckle, K. A., Edwards, R. A., Fleet, G. H., and Wotton, M. 1987. Ilmu Pangan. Penerjemah Hari Purnomo dan Adiono. Universitas Indonesia Press. Jakarta.

Campbell, N.A., Jane B.R., dan Lawerance G.R., 2000. Biologi. Erlangga. Jakarta. Hal. 224-225.

Dewi, E.N. 2001. Chemical Analysis during the Processing of Dried Salted and anchovy. Journal of Costal Development, Vol 5, (number 2), 55-65.

Diniz, G.S.; Barbarino, E.; Pacheco, J.O and Lourenço, S.O. 2013. Gross chemical profile and calculation of nitrogen-to-protein conversion factors for nine species of fishes from coastal waters of Brazil. Lat. Am. J. Aquat. Res., .41(2): 254-264. 
Gerenimo. 2011. Analisis Kuantitatif Protein Dengan Metode Semimikro Kjaldhal (Online): (geronimo-neo.blogspot.com). Diakses 20 Oktober 2018.

Girrard, J.P. 1992. Technology of Meat and Meat Products. Ellis Horwood. New York.

Ika. S. A. 2011. Studi Pembuatan Konsentrasi Protein ikan (Fish Protein Concentrate) dari ikan Gabus (Ophiacephalcesstriat). Kementerian Pertanian, Indonesia.

Kompiang, L. P. 1979. Pendayagunaan Bekicot. Kongres Nasional Biologi IV. Bandung.

Khomsan, A. 2002. Susut gizi akibat proses pemasakan.

Diakses www.kompas.com. Diakses 11 Desember 2018.

Raut, S., dan Barker, G. M. 2002. Achantina fulicaBowdich and Other Achantindae as Pests in Tropical Agricultural, in Mollusca as Crop Pests. CAB International Publishing. Harmilton. New Zealand. pp. 1-60.

Prabandari R, Mangalik A, Achmad J, \& Agustina. 2005. Pengaruh waktu perebusan dari dua jenis udang yang berbeda terhadap kualitas tepung limbah udang putih (Penaeus indicus) dan udang windu (Penaeus monodon). Enviroscienteae 1(1), 24-28.

Prayogo. 2011. Enzim Mikroba (online) (www.wordpress.com).

Pharmachy Science. 2011 Pengaruh Suhu, $\mathrm{pH}$, Konsentrasi Enzim Terhadap Kecepatan Enzimatik (online): (www.pueplepharmachy.blogspot.com). Diakses 11 Desember 2018.

Riansyah. A., Supriadi. A., \& Nopianti. R., 2013. Pengaruh Perbedaan Suhu dan waktu Pengeringan Terhadap Karakteristik Ikn Asin Sepat Siam (Trichhogaster Pectorialis) Dengan Menggunakan Oven. Jurnal, (on line). Vol II, no 01 , (http:/www.thi.fp.usri.ac.id), diakses 20 Januari 2019.

Sundari, D., Almasyhuri \& Lamid, A. 2015. Pengaruh proses pemasakan terhadap komposisi zat nilai gizi bahan pangan sumber protein. Media Litbangkes, 25(4), 235-242.
Winarno. FG, Fardiaz S Fardiaz D. 1982. Pengantar Teknologi Pangan. PT. Gramedia. Jakarta. 